\title{
任意形状ブロックを対象としたー配置手法
}

\author{
中谷 直司 ${ }^{*}$, 金杉 昭德 ${ }^{*}$, 近藤 邦雄*
}

\section{A Placement Method for Arbitrary Shape Blocks}

Naoshi NAKAYA* ${ }^{*}$ Akinori KANASUGI* and Kunio KONDO*

*埼玉大学工学部（ \%338-8570 埼玉県浦和市下大久保255）

* Faculty of Engineering, Saitama University (255 Shimo-okubo, Urawa-shi, Saitama 338-8570)

概要 VLSIレイアウト手法の多くにおいては, 配置対象ブロックの形状は矩形に限定され，矩形以外のブロックを扱うこ とは困難である。また矩形以外のブロックを対象とする手法においても，配置対象ブロックの形状自由度は高くない。そこで 本論文では，従来手法では難しかった山部を含むブロックの配㯰や，配置領域を制限しての配置を可能にする，任意形状ブロ ックの配置手法を提案する。提案手法は，ブロックの形状に応じた評価值を定義し，その值を用いることで任意形状ブロック を配置する組み立て式配置手法と，その配置順序に遺伝的アルゴリズムによる制御を組み合わせたものである。また最後に， 計算機実験により本手法の有用性を示す。

\begin{abstract}
In this paper, we propose a new placement method, which can treat of arbitrary shape blocks. In the proposed method, we place the blocks using the value that is based on the shape of block. The method is able to handle the blocks that include notches with restricted layout area. We can also search effective placements because the order of placement is controlled by Genetic Algorithm. We have made computer experiments by the automatic placement tool for proposed method. The computer experiments show that the results of proposed methods are effective placements without wasteful area.
\end{abstract}

Key Words: CAD, Layout, Placement, Arbitrary Shape Block, Genetic Algorithm

\section{1. まえがき}

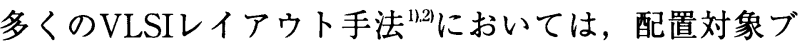
ロックの形状は矩形に限定され，矩形以外のブロックを扱 うことは困難である。また矩形以外のブロックを対象とす る手法においても，そのブロック形状はL型" ${ }^{31}$ 凸XY多角 形と呼ばれる形状なな゙に限定され，配置対象ブロックの 形状自由度は決して高くなく，凹部を含むブロックの配置 などには対応できない。また，ブロック形状に制限がない 手法 ${ }^{5}$ も提案されている。しかし, 文献4)の手法も含め, コンパクション手法であるため, 配置領域を限定して配置 を行うことは困難という問題がある。また，これらコンパ クション手法を用いるには，何らかの初期配置が必要にな るが，任意形状ブロックに適した初期配置手法は提案され ていない。

そこで本論文ではこれらの問題に対し，形状に応じた評 価值を用いることで凹部を含むブロックの配置や，配置領 域を制限しての配置も可能とする任意形状ブロックの配置 手法を提案するあ。本手法はVLSIレイアウトにおける組み 立て式配置手法の一種であるが，その配置順序に遺伝的ア ルゴリズム ${ }^{77.81}$ による制御を組み合わせることで, 組み立て
式手法に共通する欠点である配置結果の順序依存問題にも 対応可能である。また，本手法はすでに提案されているコ ンパクション手法の初期配置などにも有効である。

本手法の有用性を確認するため計算機実験を行った結 果，凹部を含む完全な任意形状ブロックの配置や，配置領 域に制限を設けての配置も可能なことが確認された。

\section{2. 任意形状ブロックの組み立て式配置手法}

本節ではブロック形状に応じた評価値を定義し，その值 を用いて任意形状ブロックを配置する組み立て式配置手法 を提案する。本手法では配置領域に制限を設けての配置を, 配置領域に制限がないときの特殊な場合としてとらえ，配 置を行う。したがって，ここでは基本となる配置領域に制 限がない場合の提案手法から述べる。なお，本手法では組 み立て式手法において重要な配置順序の制御を, 遺伝的ア ルゴリズムにより行い，良好な配置結果を得ているが，遺 伝的アルゴリズムによる制御に関しては後述する。

\section{1 配置領域に制限がない場合の手法}

配置領域に制限がない場合の任意形状ブロックの配置に ついて考える。ここでは初めに，任意形状ブロックとブロ ック形状に応じた評価値を定義する。次に，定義した評価 


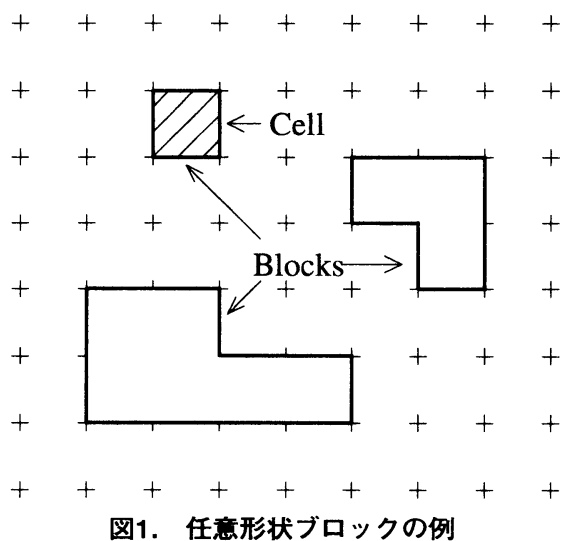

值を使いブロックを配置する手順について述べ，さらに仮 想配線長を用いて配置手順の拡張を行う。

2. 1.1 任意形状ブロックと隣接度

本手法で対象とする任意形状ブロックとは, 図 1 に示す ようないくつかのセル（1つのセルは図に斜線で示したも の）の塊である。また，レイアウト領域は碁盤の目のよう に正方形の区画が縦横に連なったものとし，1つのセルは 1 つの区画を占めるとする。

本手法では，レイアウト領域の各区画に対してブロック 形状に応じた評価値を定める。この評価値は, 各区画の周 りの 8 つ区画にいくつセルがあるかを数えたものであ り，その区画にセルを置いたとき，すでに配置されている セルと隣接する度合を示している。したがって，以下では この評価值を「隣接度」とよぶこととする。すなわち座標 $(x, y)$ の区画の隣接度 $R_{x y}$ は次式で与えられる。

$$
R_{x y}=\sum_{i=-1}^{1} \sum_{j=-1}^{1} S_{x+i, y+j}
$$

\section{ただし $S_{x y}$ :座標 $x, y$ の区画に} セルが存在するとき 1

$$
\text { " しないとき } 0
$$

なお，隣接度はすでにセルが配置されている区画につい ては定義しない。

例として図 2 の場合, 中央の区画（座標 $(x, y))$ の隣 接度は式(1)において, 座標 $(x, y+1)$ と $(x+1, y)$ と $(x+1, y+1)$ の区画にセルが存在するので,

$$
\begin{aligned}
R_{x y} & =0+0+0+0+0+1+0+1+1 \\
& =3
\end{aligned}
$$

となり，隣接度は 3 である。同様にすべての区画の隣接度

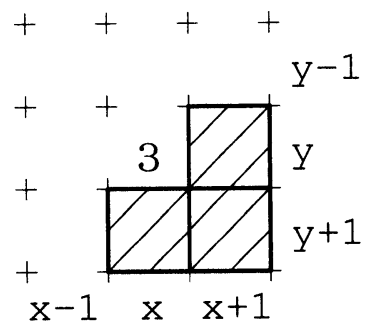

図2. 隣接度の例
を求めることができる。

\section{1.2 隣接度による配置}

前述したように隣接度はその区画にセルを配置したと き，すでに配置されているセルと隣接する度合を示してい る。そこで，ブロックを配置するときは配置した区画の隣 接度の和が最大になる区画に配置すると効率がよく，チッ プ面積の最小化にもつながる。したがって，ブロック配置 の手順は以下のようになる。

・ステップ 1 ：レイアウト領域の各区画に対して式(1) に従い，隣接度を求める。

・ステップ 2 ：ブロックを配置したとき，隣接度の和が 最大になる区画を選ぶ。なお，このときすでにセル の存在する区画を選ぶことは許されない。

・ステップ 3 : ステップ 2 で選んだ区画にブロックを配 置する。

・ステップ 4 ：配置するブロックがなくなるまでステッ プ 1，2，3 を繰り返す。

例として図3-aのようにセルがすでに配置されていると きに，図3-bのブロックを配置する場合を考える。ステッ プ 1 に従い隣接度を求めると, その分布は図3-cのように なる（図に示した以外の区画の隣接度は 0 である）。この 隣接度分布から考えてステップ 2 で選ばれる区画は, 隣接 度の和が 8 で図3-dの斜線の部分になる。したがって，ス テップ 3 で配置した結果は図3-eとなる。ここでまだ配置 するブロックが残っている場合は, 図3-eに示したセル配

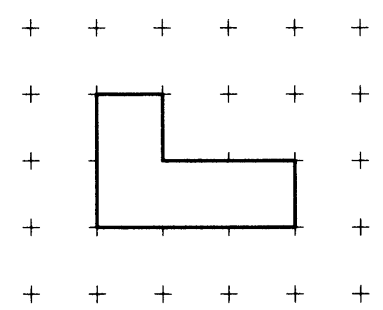

a. 配置済みブロック

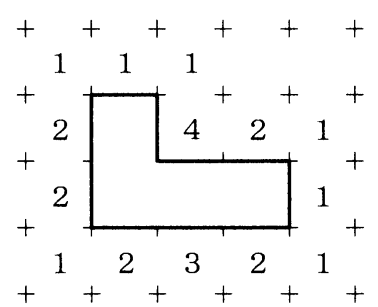

c. 隣接度の分布

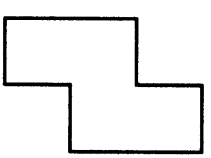

b. 次に配置するブロック

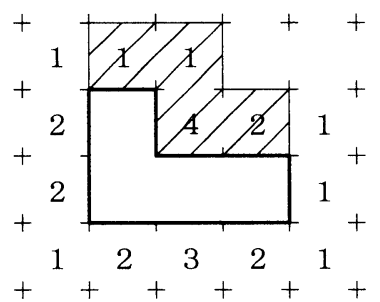

d. 隣接度の和が最大になる区画

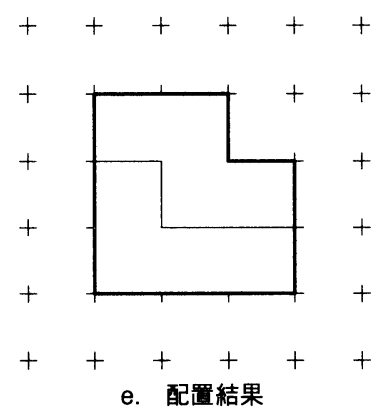

図3. 隣接度による配置の例 
置に対し隣接度分布を求め（つまり，ステップ 1 に戻る）， 同様に繰り返す。以上が今回提案する組み立て式配置手法 の基本である。

なお，すでに述べたように，本手法は配置対象である任 意形状ブロックを, 正方形のセルが縦横に連なったものと している。したがって，ブロック各辺の長さはセルの長さ の整数倍に制限され，この点での自由度は決して高いとは いえない。もちろんセルを十分に小さく考えれば，理論的 にはどのような精度でもブロックを表現できるが，その場 合, 精度に応じた処理時間の增大を避けることはできない。 そこで，長さについて高い精度を必要とするときは実用性 を考慮して，次のような方法で本手法を用いることを提案 する。まず，ブロックの各辺の長さを実用上問題のない程 度に近似し，本手法を用いて配置する。その上で，近似し たブロックを本来のブロックに置き換える。すると，ブロ ック同士の重なりや，あるいは無駄領域を生じることにな るが，それらを解消するコンパクション手法淿はすでに提 案されている。そこで, この従来手法を用いてコンパクシ ヨンをかける。つまり, 本手法を使って従来のコンパクシ ヨン手法の初期配置を与えることで, 長さについて十分な 精度を持ち, なおかつ実用的な処理時間での配置が可能と なる。

\section{1 .3 仮想配線長による拡張}

隣接度は形状に応じた評価值であるため, 形状が対称の 場合，隣接度の分布も対称となり，ブロックを配置したと きに隣接度の和が最大になる区画も複数になる。そこで配 置区画候補が複数になったときの選択法として，他の評価 法との併用が必要となる。本手法では仮想配線長を用いる ことにし，これによりブロック配置の手順は次のように拡 張される。

・ステップ 1 ：レイアウト領域の各区画に対して式(1) に従い隣接度を求める。

・ステップ 2 ：ブロックを配置する区画を選ぶ。なお,

このとき，すでにセルの存在する区画を選ぶことは 許されない。

・ステップ 2.1 ：ブロックを配置したとき，隣接度の 和が最大になる区画を選ぶ。

・ステップ 2.2 : ステップ 2.1 で選ばれた区画が複数

存在するときは，その中から配置したとき仮想配線 長が最短になる区画を選ぶ。

・ステップ 2.3 : ステップ 2.2 で選ばれた区画も複数 存在するときは，それらの区画は等価として，探索 時に先に探索された区画を選ぶ。

・ステップ 3 : ステップ 2 で選んだ区画にブロックを配

置する。

・ステップ 4 : 配置するブロックがなくなるまでステッ

プ $1,2,3$ を繰り返す。

ステップ 2.2 での仮想配線長は，各ネットごとにそれ
を構成する端子を内包する最小矩形を考え, その周囲長の $1 / 2$ をそのネットの仮想配線長とするものを採用する。な お本手法の場合, 配置過程で仮想配線長を算出する必要が あるため，ネットを構成するすべての端子が配置済みとは 限らない。そこで, 配置過程では配置されていない端子は 無視し, 配置済みの端子のみで仮想配線長を算出する。す なわち，ネット $n_{i}$ に含まれる配置済み端子のリストを $P_{i}=\left(p_{j} \cdots p_{k}\right)$ とし, それらの端子の $X$ 座標を $p_{j . x}, y$ 座標を $p_{j . y}$, とするとネット $n_{i}$ の仮想配線長 $n_{i . \text { length }}$ は,

$$
n_{i, \text { length }}=\max _{P_{i}}\left(\left|p_{j, x}-p_{k, x}\right|\right)+\max _{P_{i}}\left(\left|p_{j, y}-p_{k, y}\right|\right)
$$

となり, したがって総ネット数を $C$ とすると, 総仮想配線 長Dは,

$$
D=\sum_{i=1}^{C} n_{i, \text { length }}
$$

となる。また，上記手順ではステップ 2.3 が定められて おり, 探索順という明確な根拠のない選択がなされている。 しかし，本手法では仮想配線長の算出が端子位置に基づい ているため, 実際的なブロックではステップ 2.2 で仮想 配線長が最短になる区画が複数存在することは，きわめて まれになる。なお, 本論文で後述する計算機実験の最終配 置結果においても，ステップ 2.3 の利用はなされていな い。ただし, 配置済みブロックと配置しようとしているブ ロックの間にネットが存在しない場合にはステップ 2.2 での特定ができないため，ステップ 2.3 が適用される。 しかし，こういった場合は，複数ある配置区画候補のいず れに配置しても等価であるとして，本手法では探索順によ る配置を採用した。

\section{2 配置領域に制限がある場合の手法}

次に，配置領域に制限がある場合について考える。すで に述べた配置領域に制限がない場合においては，レイアウ 卜領域は無限の広がりを持つものとして扱ってきた。そこ で配置領域に制限がある場合においても同様に，レイアウ 卜領域は無限の広がりを持つものとする。そして配置領域 制限は, レイアウト領域の配置可能区画以外はすべてセル で埋めつくされている，とすることで実現する。これによ り，配置領域に制限がある場合においても同様に隣接度を 求め, その和が最大になる区画に配置するという手法を用 いることができる。ただし，この場合，配置可能区画に制 限が存在するため, 配置対象となるブロックがすべて配置 可能とは限らない。そこで, 配置手順は次のように修正さ れる。

・ステップ 1 ：レイアウト領域の各区画に対して式(1) に従い隣接度を求める。

・ステップ 2 ：ブロックを配置する区画を選ぶ。なお, このときすでにセルの存在する区画を選ぶことは許 されない。また，すでに十分な配置可能区画が存在 しないときは, 未配置のブロックがあっても配置手 
順を終了する。

・ステップ 2.1 ：ブロックを配置したとき，隣接度の 和が最大になる区画を選ぶ。

・ステップ 2.2 : ステップ 2.1 で選ばれた区画が複数

存在するときは, その中から配置したとき仮想配線

長が最短になる区画を選ぶ。

・ステップ 2.3 : ステップ 2.2 で選ばれた区画も複数

存在するときは, それらの区画は等価として, 探索

時に先に探索された区画を選ぶ。

・ステップ 3 : ステップ 2 で選んだ区画にブロックを配

置する。

・ステップ 4 : 配置するブロックがなくなるまでステッ

プ 1，2，3 を繰り返す。

例として， 4 行 5 列の配置領域制限がある場合について 述べる。このときレイアウト領域は図4-aのように $4 \times 5$ の配置可能区画を残してセルで埋めつくされているとして 考える（図に示した以外の区画は, すべてセルで埋めつく されている)。これに対し隣接度を式(1)に従い求めると, 図4-bのよjな分布が得られる（図に示した以外の区画の 隣接度は 0 である)。後は配置領域に制限がない場合と同 様に，すでに述べたブロック配置の手順に従いブロックを 配置する。なお，この例では配置領域制限を矩形としたが, 本手法としては領域制限が矩形である必要はない。たとえ 領域制限が非矩形であっても, 隣接度を求め配置すること は可能である。

また，配置領域制限内に配置対象のブロックが収まるか どうかは重要な問題ではあるが, 今のところそれを事前に 知る方法は知られていない。もちろん, 領域制限の面積よ りもブロックの総面積が大きい, 言い換えるならば配置可 能区画の数よりも，ブロックの総セル数が多い場合は収ま らないのは明らかである。しかし，面積の大小関係に問題 がないからといって必ずしも収まるとは限らない。本手法 において配置領域制限内に配置対象のブロックが収まるか どうかは，一般的な「ポリオミノの敷き詰め」問題と同様 な問題といえるが，この問題において可能を証明する手段 がないように, 本手法も収まることを証明する手段はない。 ポリオミノの敷き詰めと同様に，パリティを使った方法で 不可能を証明9することはできるが，それは可能を証明し たことにはならない。すなわち, 収まらないと証明されな

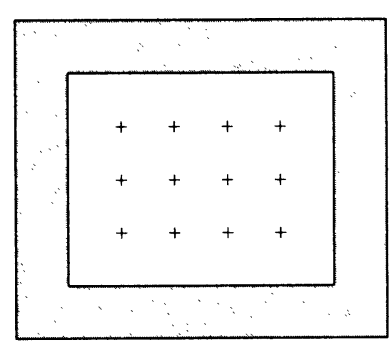

a. 配置領域制限の例

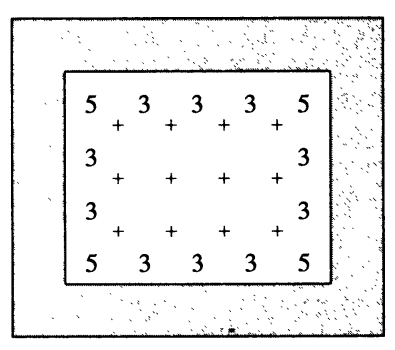

b. 配置領域制限の隣接度の例
园4. 領域制限があるときのレイアウト領域
かったとしても収まるとは限らない。あくまでも収まる可 能性があるだけであり, 実際に収まるかどうかは別の問題 である。以上のような理由から, 配置領域制限内に全ブロ ックが収まるかどうかを事前に知ることは現状では困難で ある。

\section{3. 遗伝的アルゴリズムによる配置順序制御}

本手法では配置結果は配置順序に依存する。これは本手 法が組み立て式手法の一種であるため, 配置処理過程では 全体的な見通しがなされないことに関係する。すなわち, 図 5 のような $\mathrm{A}, \mathrm{B}, \mathrm{C}$ の 3 つのブロックを配置するとき, $\mathrm{A}, \mathrm{B}, \mathrm{C}$ の順で配置すると図5-aのような結果が得られ, A， C，Bの順で配置すると図5-bのような結果になる。 この場合, 最終的結果としては図5-aの配置結果が形状と しては優れているが, これは手法としてこの配置を目指し ていたわけではなく, 配置順序から偶然に得られた結果に すぎない。すなわち配置結果は配置順序に強く依存するた め, 本手法では配置順序に適当な制御を必要とする。そこ で本研究では遺伝的アルゴリズム（GA）を用いて，本手 法に最適な配置順序を求めることとする。GAは生物が遺 伝と進化により環境に適応することに範をとった最適解探 索アルゴリズムの一つであり, 広範囲にわたる探索に威力 を発揮することで知られている。しかし，GAを用いて順 列組み合わせ問題を解く場合には, コーディングやオペレ 一夕に何らかの工夫をしなければ満足のいく解は得られな い $^{101}$ 。そこで本手法では, 次のようなコーディングの工夫 により問題を解決する。

ブロックの配置順序を $T=\left(t_{1} \cdots t_{N}\right)$ とし，またブロックを 適当な順序で並べたリスト $W$ (定数) を用意する。そして, 墦目に配置するブロックを，未配置ブロックリスト $W-$ $\left\{t_{1}, \ldots, t_{i 1}\right\}$ の何番目であるかを表し, これを遺伝子 $l_{i}$ とし, リスト $L=\left(l_{1} \cdots l_{N}\right)$ を染色体とする。このコーディングにより， 遺伝子型と表現型が一対一に対応づけられ, 通常のオペレ 一夕の適用が可能になる。なお，このコーディングは Grefenstetteらによる巡回セールスマン問題のための方法 ${ }^{11}$ を，ブロックの配置順序に応用したものである。

例としてブロックの配置順序が $T_{1}=(B D A C E)$ のとき のコーディングを考える。ブロックを適当な順序で並べた リストを $W=(A B C D E)$ とすると， 1 番目に配置するブ ロック Bは, 未配置ブロックリ゙ストWの 2 番目なので遺伝 子 $l_{1}$ は 2 となる。次に 2 番目に配置するブロック $D$ は, 未

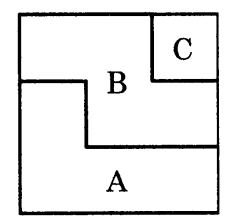

a. ABCの順に配置

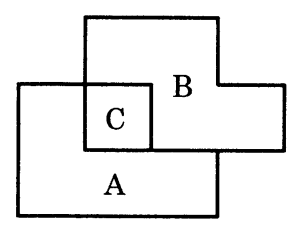

b. ACBの順に配置
図5. 配置順序依存の例 
配置ブロックリスト $W-\{B\}=\left(\begin{array}{llll}A & C & D & E\end{array}\right)$ の 3 番目なので遺 伝子 $l_{2}$ は 3 となる。以下これを繰り返すと染色体はリスト $L_{1}=\left(\begin{array}{llll}2 & 3 & 1 & 1\end{array}\right.$ 1) として求まる。また, ブロックの配置順序が $T_{2}=\left(\begin{array}{llll}E & D & C & B\end{array}\right.$ A)のときの染色体は, リスト $L_{2}=\left(\begin{array}{lllll}5 & 4 & 3 & 2 & 1\end{array}\right)$ となる。GAでは，これらの染色体を交叉することで新し い染色体を作り探索を行うが，ここでは上記のコーディン グの工夫により, 通常の交叉を用いての探索が可能になる。

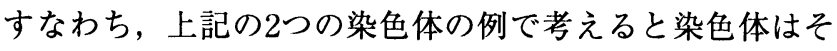
れぞれ,

$L_{1}=\left(\begin{array}{lllll}2 & 3 & 1 & 1 & 1\end{array}\right)$

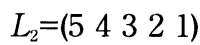

である。これを 2 番目の遺伝子と 3 番目の遺伝子の間で交 叉したとすると, 新しい染色体は,

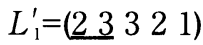

$$
\begin{aligned}
& L_{2}^{\prime}=\left(\begin{array}{llll}
5 & 4 & 1 & 1
\end{array}\right)
\end{aligned}
$$

となる。これをコーディングと逆の手順でブロックの配置 順序に戻すと，

$$
T_{1}^{\prime}=(B D E E C A)
$$

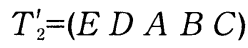

となり, ブロックの重複を含まない配置順序, すなわち順 列という条件を満足する解が得られ，効率の良い探索が可 能になる。なお, 突然変異は遺伝子 $l_{i}$, 条件 $1 \leq l_{i} \leq$ $N-i+1$ 满足する遺伝子にランダムに置き換えることで 実現する。

GAを用いる上での評価值である適応度 $f$ は, 仮想配線長 $D$ と総ネット数 $C$, さらに配置結果を内包する最小矩形を

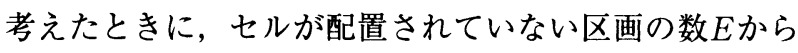

$$
f=\frac{1}{1+\alpha \frac{D}{C}+\beta E}
$$

として定義する。すなわち, 仮想配線長が短く, かつ配置 結果が隙間なくコンパクトにまとまっている方が評価が高 いとする。また，配置領域に制限がある場合では，最終的 に未配置のブロックが存在することが考えられるが，この

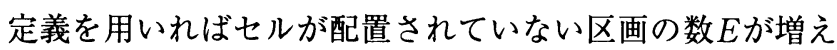
るため評価が低くなり，世代を重ねることで淘汰されると 考えられる。なお， $\alpha$ と $\beta$ は，仮想配線長と配置結果の隙 間という二つの評価要素の, 適応度 $f$ に占める割合を決定 する係数であり，配置の目的に応じて設定する。

GAによる配置順序制御の導入により, 本配置手法全体 は次のようになる。

・ステップ 1 : 初期集団として $M$ 個の個体を生成する。 このとき各個体の持つ情報は, 上記のコーディング によりブロックの配置順序を表している。

・ステップ 2：各個体に対し次の処理を行う。

・ステップ 2.1 : 個体の持つ配置順序情報に従い, 前 述のブロック配置の手順を使って配置可能なすべて のブロックを配置する。このとき配置結果は配置順
序により，一意に決定される。

・ステップ 2.2 : 配置結果から仮想配線長 $D$ と空き区画 数 $E$ を求め, 式(2)に従い適応度 $f$ 算出する。

・ステップ 3 : ステップ 2 で求めた適応度に従い, 選択, 交叉, 突然変異などのオペレー夕により個体集団を 進化させる。

・ステップ 4 ：ステップ 2,3 を一世代とし定められた 世代数を繰り返す。

・ステップ 5 : 最終的に得られた最も優れた適応度を持 つ個体の配置結果を，本手法の配置結果とする。

\section{4. 計算機実験}

本手法の有用性を確認するため, 計算機実験を行った。 遺伝的アルゴリズムのオペレータとパラメータは, 経験的 に次のように決定した。これは以下の実験において共通で ある。

・適応度：適応度 $f$ は式(2)において，仮想配線長による 評価と配置結果の隙間による評価を適度に取り入れ ることを目的に， $\alpha=\beta=1$ とする。

- 選択：適応度比例戦略とエリート保存戦略を用いる。 なお，このときのエリート保存数は 1 とする。

・交叉：一点交叉を用いて, 交叉確率 $p_{c}$ は 0.95 とする。

·突然変異 : 突然変異確率 $p_{m}$ は0.1とする。

まず，図 6 のブロックを配置する実験例を示す。このと き個対数 $M$ を 30 , 世代数 $T$ を 20 とした。配置領域に制限を 設けないときの配置結果を図 7 に示す。なお，配置順序は ブロック番号 $5,3,2,6,4,1,0$ の順で, 仮想配線長はセ

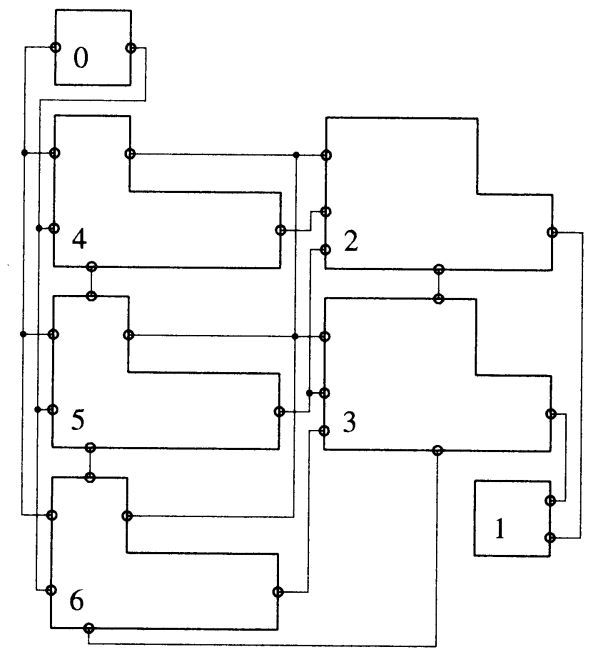

図6. 配置対象ブロックの例 1

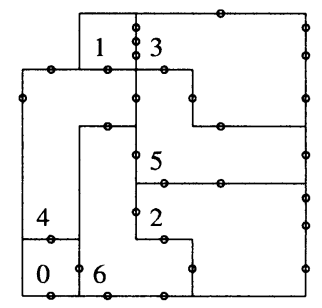

図7. 領域制限がないときの配置（例 1 ） 
ルの一辺を 1 として46.5である。配置結果を内包する最小 矩形を考えると $5 \times 5$ の区画になり，その中で左上角の区 画が空いているので空き区画数は 1 となる。また, 配置領 域に制限がある場合についても計算機実験を行った。ここ でも例として図 6 に示したブロックを配置することを考え る。図 6 に示したブロックの総セル数は 24 , そこで 4 行 6 列の配置領域制限を設けることとした。結果は図 8 に示す ように，与えられた配置領域内にすべてのブロックが配置 された。さらに本手法においては, 配置領域制限は必ずし も矩形である必要はない。そこで図 6 に示すブロックを図 9 のような非矩形の配置領域へと配置した。結果は図10に 示すように，与えられた配置領域内にすべてのブロックを 配置することができた。

次に50個のブロックを配置する実験例を示す。このとき 個対数 $M$ を 100 , 世代数 $T$ を 50 とした。この例では総セル 数は240, そこで15行16列の配置領域制限を設ける。その 結果，図11に示したように，50個のブロックすべてを隙間 なく配置することができた。なお，この例では凹部を持つ ブロックが10個存在するが，そのすべてが無駄領域を生ず ることなく配置された。また, 非矩形の配置領域への配置

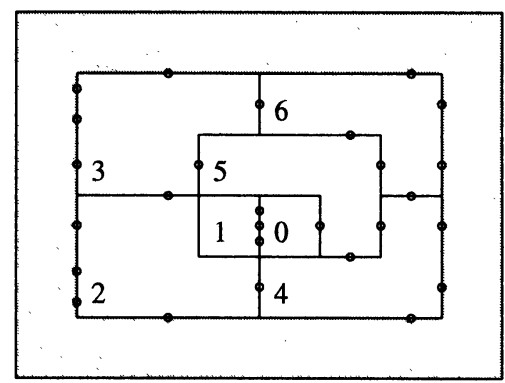

図8. 領域制限があるときの配置（例 1)
も行い, 図12に示したようにすべてのブロックが配置され ることを確認した。

\section{5. むすび}

本論文ではVLSIレイアウトにおける組み立て式配置手 法として, ブロック形状に応じた評価値を定義することに より，任意形状ブロックの配置を行う一手法を提案した。 本手法の特徴は以下の通りである。

1. 従来手法では難しかった凹部を含む, 任意形状ブロ ックの配置が可能である。

2. 非矩形の領域制限を含む, 配置領域を制限しての配

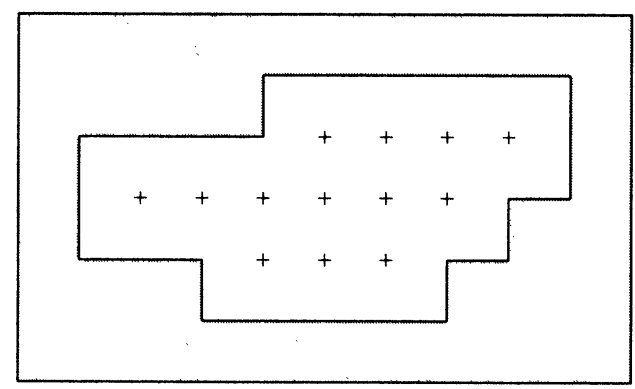

図9. 非矩形の領域制限

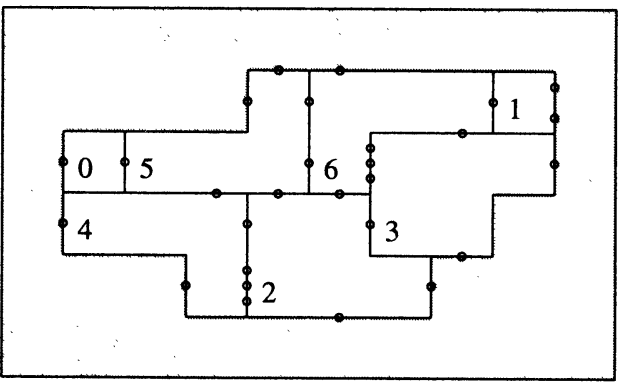

図10. 非矩形の領域制限があるときの配置（例 1 )

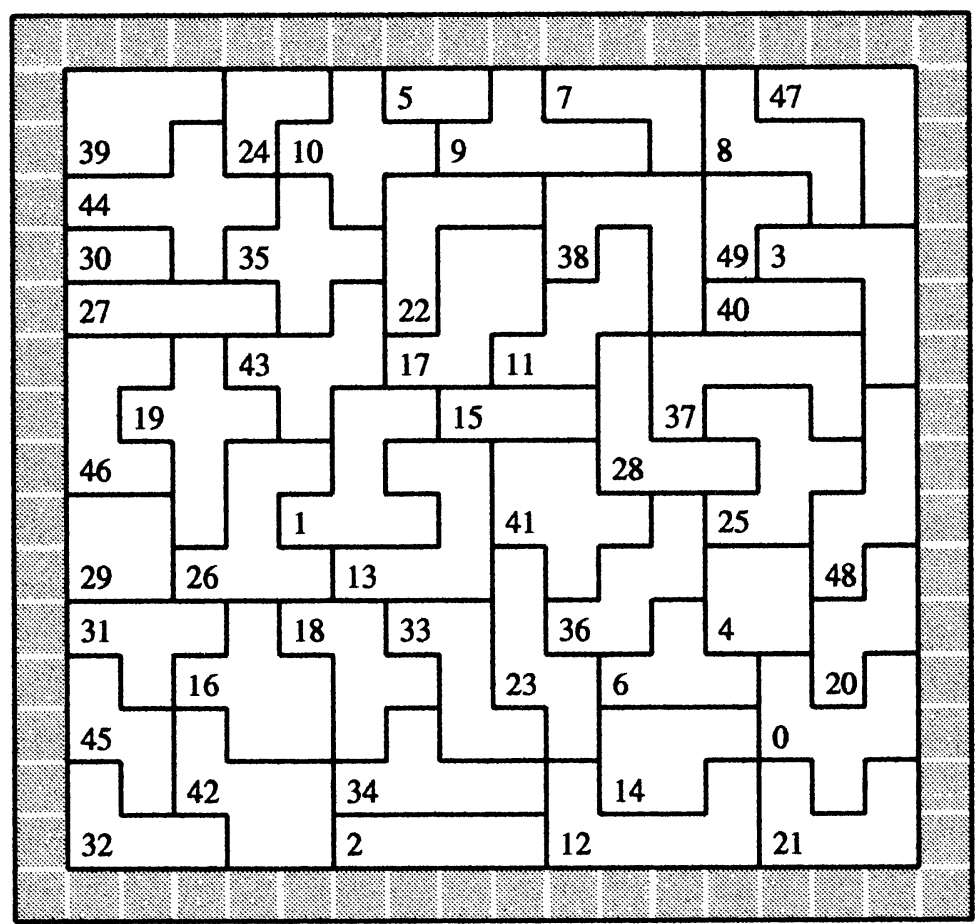

图11. 領域制限があるときの配置（例 2） 


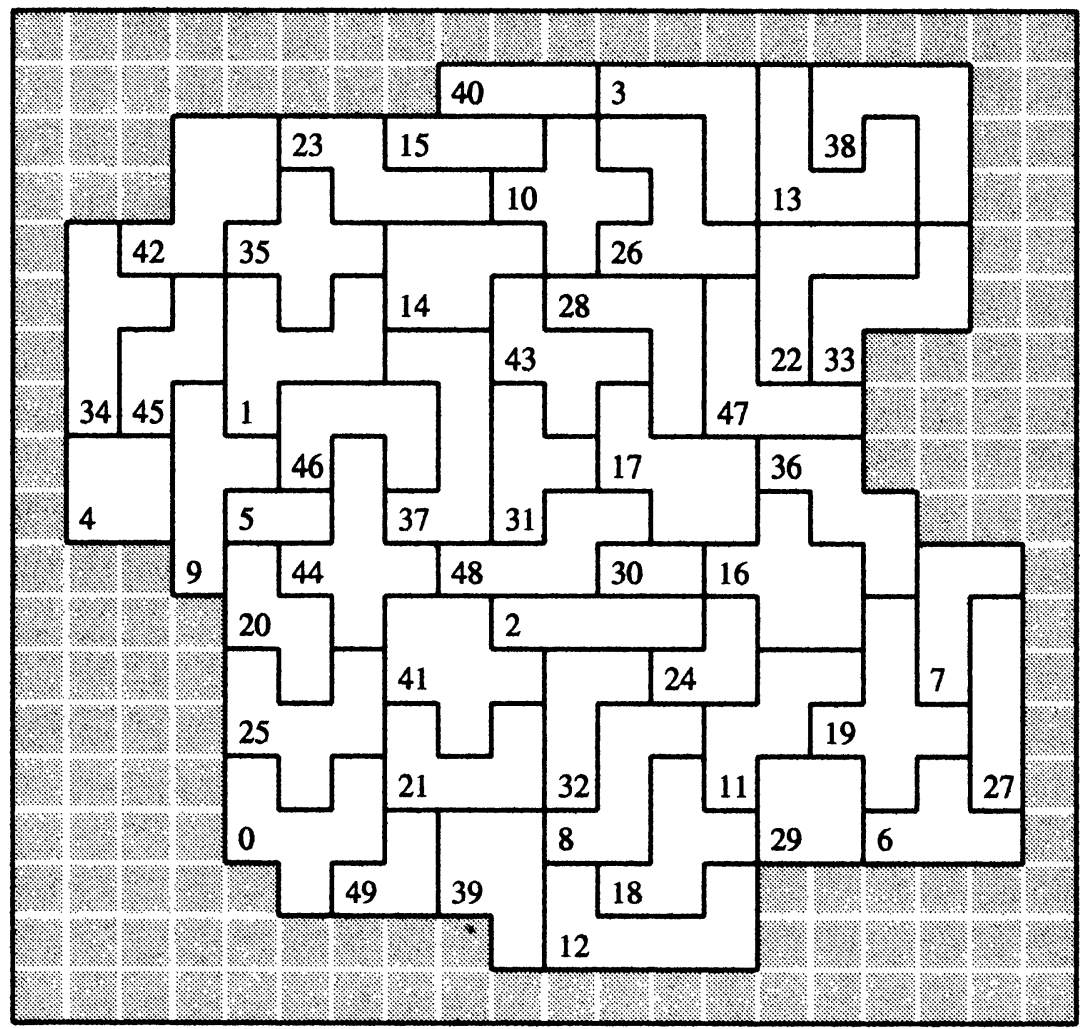

図12. 非矩形の領域制限があるときの配置（例 2）

置が可能である。

3. 配置順序に遺伝的アルゴリズムによる制御を組み合 わせることで，組み立て式手法に共通する欠点である 配置結果の順序依存問題に対応できる。

4. 従来のコンパクション手法のための初期配置を与え ることに利用可能である。

また, 本手法の有用性を確認するため計算機実験を行い， 凹部を含む完全な任意形状ブロックの配置や，配置領域に 制限を設けての配置も可能であることを示した。

(1998.4.20-受理１998.7.13-再受理)

\section{文献}

1) 渡辺孝博：“LSIレイアウト自動設計の現状と可能性”，信学 誌, Vol.76, No.7, pp.774-782, Jul. 1993.

2）佐藤真司，堤 定雄，後藤源助：“マスタスライスセルの自 動発生”，信学技報，ICD88-70，1988.

3) D.F.Wong and C.L.Liu: "Floorplan Design for Rectangular and L-shaped Modules", Proc. Intl. Conf. on ComputerAided-Design, pp.520-523, 1987.

4) 大村道郎，宮尾淳一，菊野 亨，吉田典可：“VLSIのブロ ック配置における重なり除去問題”，信学論(A), Vol.J72-A
No.7, pp.1093-1100, Jul. 1989.

5) J.A.Hudson, J.A.Wisniewski and R.C.Peters: "Module Positioning Algorithms for Rectilinear Macrocell Assemblies", 21st Design Automation Conference, pp.672675,1984

6) 中谷直司，金杉昭徳，森末道忠：“任意形状ブロックの一配 置手法”, プリント回路学会第 8 回学術講演大会講演論文集, pp.85-86, Mar. 1994.

7）北野宏明：“遺伝的アルゴリズム”，産業図書，1993.

8) D.Lawrence: "Handbook of Genetic Algorithms", Van Nostrand Reinhold, 1991.

9) J.D.ビースリー：“ゲームと競技の数学”，サイエンス社, 1992.

10) N.Nakaya and K.Kondo: "A Novel Coding Technique for Genetic Placement Method”, Proc. of ITC-CSCC'97, pp.661664, 1997.

11) J.Grefenstette, R.Gopal, B.Rosmaita and D.VanGucht :

"Genetic Algorithms for the Traveling Salesman Problem", Proc. of 1st Int. Conf. on Genetic Algorithms and Their Applications, pp.160-168, 1985. 